\title{
A Fossil Dicot Wood Aeschynomenoxylon Mohgaonsesp.Nov From The Deccan Intertrappean Beds Of Mohgaonkalan, M.P., India.
}

\author{
A.M. Yadav ${ }^{1}$, M. Bhowal ${ }^{2} \&$ S. D. Narkhede ${ }^{3}$ \\ ${ }^{I}$ (Department of Botany, J.M. Patel College , Bhandara, (MS) India). \\ ${ }^{2}$ (Department of Botany, Hislop College, Nagpur, (MS) India). \\ ${ }^{3}$ (Department of Botany, Govt. Sci. College, Gadachiroli, (MS) India).
}

\begin{abstract}
The Deccan Intertrappean flora is mostly silicified and often very well preserved, representing the groups Thallophyta (fungi, algae and charophytes), water ferns, conifers and angiosperms with both monocotyledons and dicotyledons. The present wood is collected from the Deccan Intertrappean beds of Mohgaonkalan. The wood is angiospermic diffuse porus, vessels solitary and in multiples of two, usually small, occasionally of medium size. Xylem parenchyma scanty with paratracheal vasicentri type, Intervascular pitting are simple and alternate.Perforation plate simple. Fibers are non-septate and storied. Wood rays uniseriate only. Rays are homogenous and made up of procumbent cells only. It show its affinities with the reported species of Aeschynomene.
\end{abstract}

Keywords: Angiospermic,Homogenous, Intertrappean, Mohgaonkalan and Thallophyta.

\section{Introduction}

The Deccan Traps are a large igneous province located on the Deccan Plateau of west-central India (between $17^{\circ}-24^{\circ} \mathrm{N}, 73^{\circ}-74^{\circ} \mathrm{E}$ ) and one of the largest volcanic features on Earth. They consist of multiple layers of solidified flood basalt that together are more than $2,000 \mathrm{~m}(6,562 \mathrm{ft})$ thick and cover an area of $500,000 \mathrm{~km}^{2}$ $(193,051 \mathrm{sq} \mathrm{mi})$ and a volume of 512,000 $\mathrm{km}^{3}(123,000 \mathrm{cu} \mathrm{mi})$. The term "trap", used in geology for such rock formations, is derived from the Dutch word for stairs and refers to the step-like hills forming the landscape of the region.

The present wood is collected from the Deccan Intertrappean beds of Mohgaonkalan. The plant remains are preserved in the black and brown cherts at this locality. The preservation of plant in black chertsis comparatively better than in the brown cherts. This locality has yielded varied plant parts like roots, woods, leaves, flower, fruits and cones too. Many dicotyledonous woods have so far been described from this wellknown locality by number of workers [1,2,3] showing affinities to the families like Myrtaceae, Combretaceae, Euphorbiaceae. A preliminary study of the present material resulted in the finding of fossil woods showing similarities with the already known species of Aeschynomene, such as Aeschynomenoxylon, Aeschynomenetertiarum (Prakash) [4], Aeschynomenetertiara[5] and Aeschynomenoxylonmalwaensis[6] which is described below.

The genus AeschynomeneLinn. Consist of about 150 species[7] distributed both in the Old and the New World. It is chiefly a tropical genus with a few species occurring in warm temperate areas. About one half of the species are hydrophytes, found in marshes, mud holes, rice paddies, along the stream banks. The others are more xeric, found in dry, waste places, pine barrens, oak woods, or on the rocky hillsides and sandy beaches[8].

\section{Material and Method}

The material was thoroughly ground to make the surface even. It was etched with hydrofluoric acid and washed under running water. Peels were then taken out in three planes, T.S, T.L.S and R.L.S. Slides were prepared. These were studied under the microscope and camera lucida sketches were drawn.

\section{Description}

The wood is diffused, porous, decorticated without any growth rings. Vessels are not visible to the naked eye. The anatomical details are as follows.

1.1. Vessels:Vessels are mostly solitary or in multiples of two, usually small, occasionally of medium size and distributed quite widely, its diameter varying between $62 \mu \mathrm{m}$ to $100 \mu \mathrm{m}$. when seen in a cross- section, the vessels and fiber cells look almost alike except that the vessels are slightly thicker walled.Pores are nearly circular in cross section (Plate I- Fig.1,4,5\&Plate II-Fig.1,2). The vessel frequency is 2 to 3 per sq. mm. The vessel member length varies from $322 \mu \mathrm{m}$ to $401 \mu \mathrm{m}$. Vessels are contiguous with rays on one or on either sides. 
Perforation plates are simple. Intervascular pittings are alternate and simple.Pit pores are mostly circular with the diameter varying between $63 \mu \mathrm{m}$ to $70 \mu \mathrm{m}$ (Plate I - Fig.7\&Plate II-Fig.5).

1.2. Xylem parenchyma: Parenchyma is scanty and not well preserved. It is predominantly paratracheal vasicentric type. It is one celled thick forming a single layered sheath around the vessels. Cells of parenchyma are mostly flattened (Plate I- Fig.1,2\&Plate II-Fig.1,2).

1.3. Wood fibres: They are abundant forming the ground mass of the wood. In transverse section they are pentagonal to polygonal in shape and shows irregular cavity formation in between fibres, it is arranged in 4 to 5 layers (Plate I- Fig.1,2,5\&Plate II-Fig.1,2). Sometimes walls of some of the cells are slightly irregular presumably owing to deformation during preservation.They are thick walled and are compactly arranged in radial rows. Fibers are non- septate, pointed from both the ends and storied. The thickness of fiber wall is $83 \mu \mathrm{m}$ to $95 \mu \mathrm{m}$ (Plate I- Fig.3,4\&Plate II-Fig.3,4).

1.4. Wood rays: The wood rays are uniseriate only. It is 6 to 10 cells in height (Plate I- Fig.3,6\&Plate IIFig.3). Ray system is homogenous consisting of procumbent cells only. Simple pits are present on radial wall. Rays are contiguous with fibers. Frequency of ray is 18 to 20 sq per.mm and breadth is about $19.10 \mu \mathrm{m}$ to 24.16um (Plate I- Fig.3,4,6\&Plate II-Fig.3,4).

\section{Identification:}

From the above description it is clear that the specimen under investigation reveals the following important anatomical characters which are of great help in its identification such as, Angiospermic diffuse porus wood, vessels solitary or in multiples of two usually small, occasionally of medium size.Xylem parenchyma scanty with paratracheal vasicentri type, Intervascular pitting are simple and alternate.Perforation plate simple. Fibers are non-septate and storied. Wood rays uniseriate only.Simple pits are present on radial wall. Rays are homogenous and made up of procumbent cells only.

\section{Discussion:}

Structural features of the fossil wood indicate, after extensive comparison, that its closest affinities are with the modern genus AeschynomeneLinn. Of the family Leguminosae(Papillionaceae) such as small to medium sized vessels, parenchyma vasicentric to aliform,fine homogenous rays and simple pits on their radial wall $[9,5,10]$.

So, the comparison is made with the reported wood of the genus Aeschynomene. The fossil wood was compared with the only known species ofAeschynomenoxylon,A. tertiarum (Prakash) [4] described from the Deccan Intertrappean beds of Mohgaonkalan. The present fossil wood shows some similarities with the A.tertiarum such as vessels smaller in size, frequency, xylem rays uniseriate rarely partially biseriate but it mainly differs in parenchyma pattern that is vasicentric and aliform to aliform- confluent and the fibres are nonstoried. But in present fossil wood, parenchyma is paratracheal vascicentric and fibres are storied.

Aeschynomenetertiara[5] shows vessels diffuse, solitary and in multiples of two, usually small occasionally of medium size, perforation plates exclusively simple, horizontal to slightly inclined, parenchyma scanty, ray homogenous composed of procumbent cells,mostly uniseriate rarely partially biseriate, pits simple, more numerous on the radial walls than on the tangential wall.But it greatly differs from the present petrified wood in having parenchyma 1-4 seriate, occasionally slightly wavy, continous or broken tangential bands which are more or less parallel, both fusiform and strand parenchyma are found, and fibers unstoried.

The present petrified wood shows more affinities with theAeschynomenoxylonmalwaensis[6]such as wood diffuse porous, growth ring absent, vessels small to medium in size, mostly solitary and also in multiples of 2-3, perforation plate simple, intervascular pitting alternate to opposite, rays homogenous made up of procumbent cells. But it is mainly differs in parenchyma pattern that is paratracheal in the form of 1-2 seriate sheath and extending laterally to form 2-3 seriate extension of aliform to aliform-confluent. Xylem ray 1to 4 seriate, intervessel pit-pairs bordered, oval to polygonal in shape with lenticular apertures and fibres fusiform.

The close agreement in major diagnostic features as well as in numerous microscopic details of anatomical structure provides convincing evidence that the Intertrappean fossil wood is assignable to genus Aeschynomene. And it does not match with any of the reported wood of the genus Aeschynomene. So the present fossil wood has been described as a new species of Aeschynomenoxylon, A. mohgaonse, the specific name indicating its occurrence in the region Mohgaonkalan. 


\subsection{Aeschynomenoxylon sp. nov.}

\section{Diagnosis}

Angiospermic diffuse porus wood, vessels solitary and in multiples of two, usually small, occasionally of medium size.Xylem parenchyma scanty with paratracheal vasicentri type, Intervascular pitting are simple and alternate.Perforation plate simple. Fibers are non-septate and storied. Wood rays uniseriate only. Rays are homogenous and made up of procumbent cells only.

\subsection{Aeschynomenoxylon mohgaonse sp. nov.}

Angiospermic diffuse porus wood, vessels solitary usually small, occasionally of medium size and its diameter varying between $62 \mu \mathrm{m}$ to $100 \mu \mathrm{m}$. The vessel frequency is 2 to 3 per sq. $\mathrm{mm}$. The vessel member length varies from $322 \mu \mathrm{m}$ to $401 \mu \mathrm{m}$. Xylem parenchyma scanty with paratracheal vasicentri type, Intervascular pitting are simple and alternate. Pit pore circular in shape.Perforation plate simple.Wood rays uniseriate only. Rays are homogenous and made up of procumbent cells only, frequency of rays is 18 to 20 sq per. mm., and breadth is about $19.10 \mu \mathrm{m}$ to $24.16 \mu \mathrm{m}$., height of ray is $204.12 \mu \mathrm{m}$ to $233.31 \mu \mathrm{m}$. Fibers are non-septate and storied.

\section{Holotype :AMY./ Wood-3. Department of Botany, Institueof Science Nagpur. \\ Locality : Mohgaonkalan, M.P., India. \\ Horizon : Deccan Intertrappean Series of India. \\ Age : ?Upper Cretaceous.}

\section{References}

[1]. Rode, K. P.,A silicified dicotyledonous wood,Dryoxylon mohgaonse sp. nov. from the Deccan Intertrappean beds of India. Journal of Indian Botanical Society. 15(2), 1936, 131-138.

[2]. Prakash, U., Studies in the Deccan Intertrappean flora, 2 further observation on Dryoxylon mohgaonse, Rode, Palaeobotanist, 5(2), 1957, 104-108.

[3]. Shallom, L. J., A fossil dicotyledonous wood from the Deccan Intertrappean beds of Mahurzari,Journal of Indian Botanical Society, 37(4), 1958, 492-498.

[4]. Muller-Stoll and Madel, Die FossilenLeguminosen-HolzerEine Revision der mitLeguminosenverglichenenfossilenHolzer and Beschreibungenalterer und Beschreibungenalterer und neuerArten, Palaeontographica, 119(B), 1967, 95-174.

[5]. Prakash, U., Aeschynomenetertiara, a new fossil wood from Deccan Intertrappean beds at Mahurzari near Nagpur, India, Palaeobotanist, 11 (1-2), 1962, 1-6.

[6]. Bande, M. B., Aeschynomenoxylonmalwaensissp.nov from the Deccan Intertrappean Beds of India,Palaeobotanist, 27 (2), 1981, 221-225.

[7]. Willis, A Dictionary of Flowering plants and Ferns(Cambridge1973).

[8]. Rudd. V. E., The American species of Aeschynomene, Contr. United St. Nat. Herb., 32 (1), 1955, 1-172.

[9]. Metcalfe, C. R. and Chalk, L., Anatomy of the dicotyledons I and II(Oxford University Press Great Britain 1950).

[10]. Esau, K., Plant anatomy.Wiley International Edition(II) (Toppan Company, limited, Tokyo, Japan1965).

\section{Plate I}

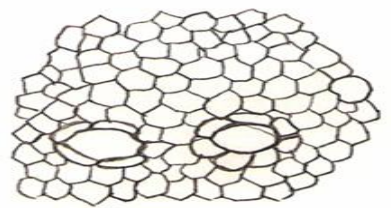

1

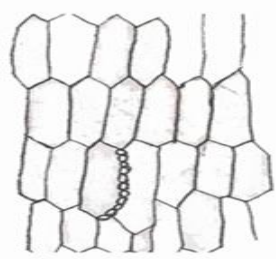

3

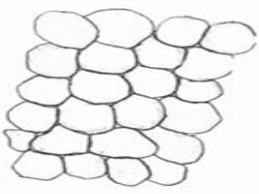

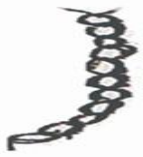

6

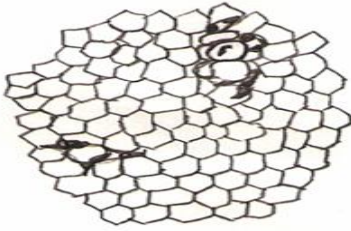

2

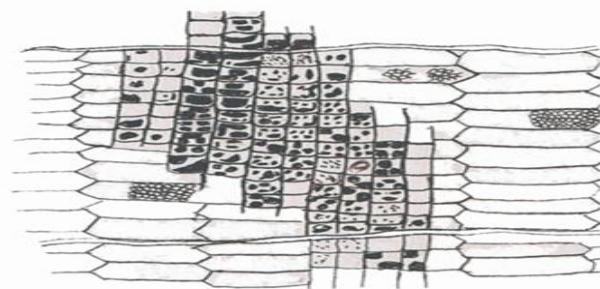

4 


\section{Explanation of Text Figures}

Fig 1-2: T.S of wood showing vessels. Fig 3: T.L.S of wood showing uniseriate medullary rays \& storied fibres. Fig 4: R.L.S of wood showing homogenous medullary rays with deposition \& storied fibres. Fig 5: T.S of wood fibresmagnified.Fig 6: Uniseriate wood rays. Fig 7: Vessel showing alternate pitting (magnified).

\section{Plate II}
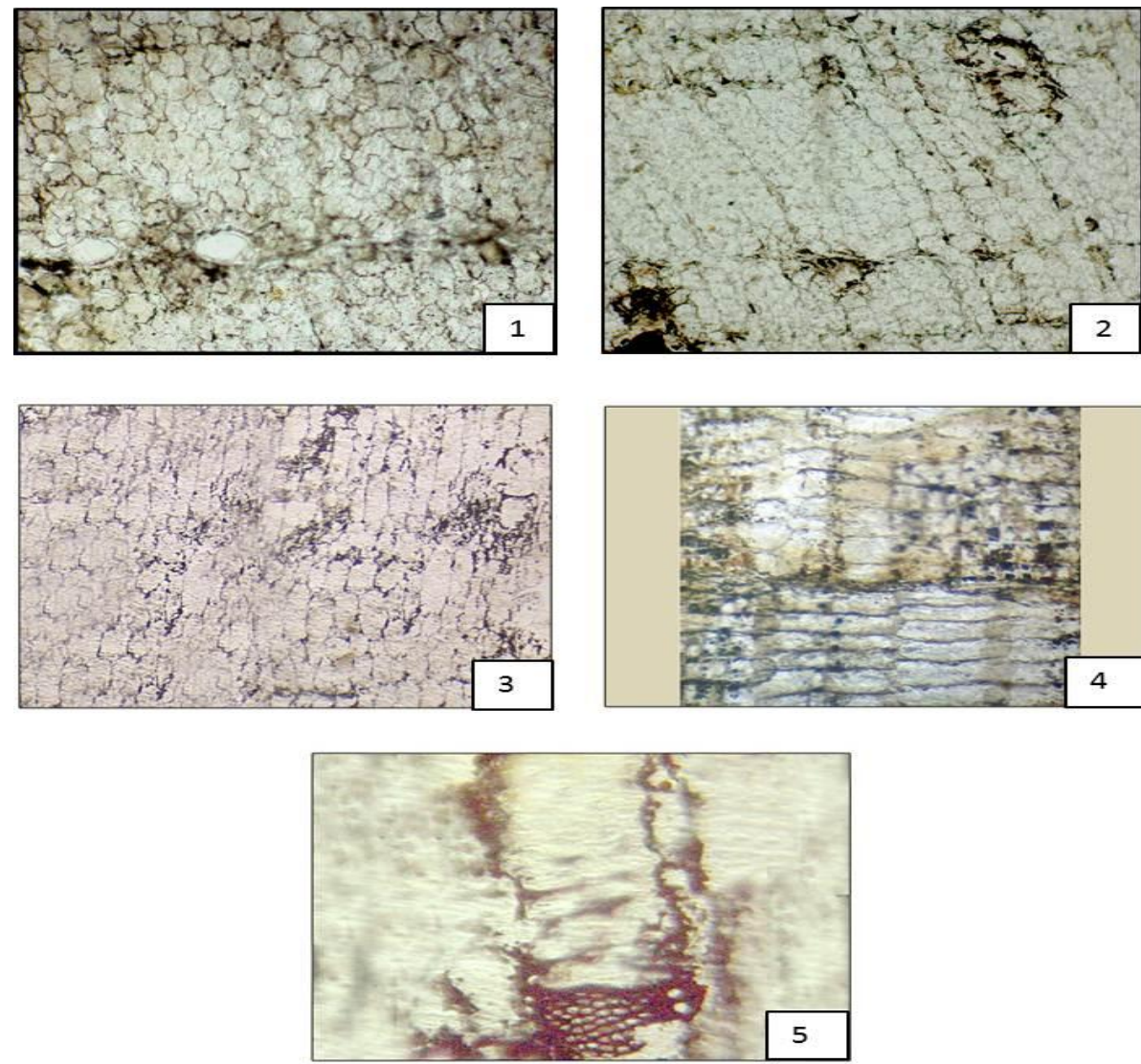

\section{Explanation of Plate Figures}

Fig 1-2: T.S of wood showing vessels (100X). Fig 3: T.L.S of wood showing uniseriate medullary rays \& storied fibres (100X). Fig 4: R.L.S of wood showing homogenous medullary rays with deposition \&storied fibres (100X). Fig 5: T.L.S of wood showing vessel with alternate pitting (400X). 